\title{
Seasonal storage of residential exhaust air and sewage waste heat
}

\author{
Janne Hirvonen ${ }^{1 *}$, Juha Jokisalo ${ }^{1,2}$, and Risto Kosonen ${ }^{1,2,3}$ \\ ${ }^{1}$ Department of Mechanical Engineering, Aalto University, Finland \\ ${ }^{2}$ Smart City Center of Excellence, TalTech, Estonia \\ ${ }^{3}$ College of Urban Construction, Nanjing Tech University, China
}

\begin{abstract}
Most Finnish residential buildings have been built before ventilation heat recovery options became mandatory. Exhaust air heat pumps are an effective way to reduce emissions, but they cannot cover all heating demand. Ground-source heat pumps can be designed to meet all loads, but they require corresponding amounts of space both above and below ground. This simulation study combines residential ventilation and sewage waste heat with a ground-source heat pump system to improve system sustainability and cost-effectiveness. A hybrid waste heat and ground-source heat pump system was shown to have $20 \%$ lower life cycle costs compared to a pure ground-source heat pump system. It also maintained sustainable ground temperature levels over the long term, while reducing above-ground space requirements by $95 \%$.
\end{abstract}

\section{Introduction}

Most of the Finnish building stock is composed of residential buildings. Most apartment buildings utilize district heating, but several studies have shown the climate benefits of ground-source heat pumps (GSHP) [1], [2]. The oldest buildings, which have the most to gain from heat pump (HP) retrofits, are also often in need of other costly renovation work, which can raise the debt levels of housing cooperatives. Thus, the large investment cost of heat pump systems can cause apprehension in many building owners. In some buildings, there can be an issue of land availability, as boreholes for GSHP systems need to be spaced far enough apart to guarantee long term operation. If not enough space is available, there is a risk of undersizing the borehole field, which can result in premature cooling of the ground and eventual system malfunction. Thus, there is a need to reduce both the investment cost and the space requirement of GSHP systems.

Most of Finnish buildings have been built before the year 2000, which means that they usually don't contain any kind of heat recovery (HR) systems. Even new buildings are only mandated to recover ventilation heat, while the heat contained in sewage is lost down the drain. Additionally, during summer there is no use for ventilation heat recovered through an air-to-air HR system. However, it has been shown that heat recovery from both ventilation [3] and sewage [4] systems using heat pumps can be cost-effective. Exhaust air heat pumps can also have a higher impact on energy consumption than ventilation heat recovery using only heat exchangers.

The benefit of GSHP vs. exhaust air heat pumps (EAHP) is that they can cover all demand, but they require large ground volumes to avoid premature cooling of their heat source. In a Swiss study, the ground around a building with GSHP was cooled down by $6 \mathrm{~K}$ over one year [5]. Solar energy was considered for regenerating the ground, but it was not economical. In another case, the ground was regenerated by waste air heat injection, which allowed the reduction of the borehole field size by $47 \%$ [6]. However, too strong temperature regeneration can prevent free cooling applications. An empirical study from Poland found out that the temperature of a borehole field was reduced by $0.6 \mathrm{~K}$ per year during heating operation, but it could be regenerated by a heat injection equivalent to $66 \%$ of annual heating demand [7].

This study aims to increase the utilization of residential waste heat by combining heat recovery systems with a ground-source heat pump system and borehole thermal energy storage (BTES). This is expected to reduce the length of boreholes required for stable long-term operation, thus lowering investment costs. In addition, we examine the potential of reducing GSHP system space requirements by tighter spacing of a borehole field. The research questions are: How does the ground temperature develop when ground-source heat pumps are used with or without support from waste heat sources? What are the cost-benefits of hybrid heat pump systems compared to a pure GSHP system?

\section{Methods and materials}

In an urban environment, designing GSHP systems with adequate heat output can be challenging due to limited space available for the boreholes. An undersized GSHP system can cause premature cooling of the

\footnotetext{
* Corresponding author: janne.p.hirvonen@aalto.fi
} 
ground, which serves as the heat source. This study examines the utilization of apartment building ventilation and sewage waste heat for improving system cost-efficiency and for reducing the size requirement of a GSHP system. Dynamic building simulation with IDA-ICE 4.8 was used to generate the heating demand profile for a typical Finnish apartment building. Then this hourly demand profile was used in TRNSYS 17 to design and test the hybrid heat recovery system.

\subsection{Building description}

The reference building used in the study was based on an existing apartment building in Helsinki. The building has been built in the year 2000, according to the building code at the time. It was equipped with mechanical exhaust ventilation, without ventilation heat recovery. The properties of the building are shown in Table 1.

Table 1. Building properties.

\begin{tabular}{|c|c|c|c|}
\hline Feature & Value & Feature & Value \\
\hline Construction year & 2000 & Ventilation & \\
\hline $\begin{array}{l}\text { U-values of } \\
\text { envelope } \\
\left(\mathrm{W} / \mathrm{m}^{2} \mathrm{~K}\right)\end{array}$ & & Type & $\begin{array}{c}\text { Mechanical } \\
\text { exhaust }\end{array}$ \\
\hline External wall & 0.28 & HR & - \\
\hline Floor & 0.36 & $\begin{array}{l}\text { Air change } \\
\text { rate }(1 / \mathrm{h})\end{array}$ & 0.5 \\
\hline Roof & 0.22 & $\begin{array}{c}\mathrm{SFP} \\
\left(\mathrm{kW} / \mathrm{m}^{3} / \mathrm{s}\right)\end{array}$ & 1.5 \\
\hline External doors & 1.4 & & \\
\hline $\begin{array}{l}\text { Windows } \\
\text { (triple-glazed, } \\
\text { clear) }\end{array}$ & 1.7 & $\begin{array}{l}\text { Radiator } \\
\text { supply/return } \\
\left({ }^{\circ} \mathrm{C} /{ }^{\circ} \mathrm{C}\right) \\
\end{array}$ & $70 / 40$ \\
\hline g-value & 0.71 & \begin{tabular}{l}
\multicolumn{1}{c}{ Heat } \\
distribution \\
efficiency
\end{tabular} & 0.8 \\
\hline $\begin{array}{c}\text { Direct } \\
\text { transmittance }\end{array}$ & 0.64 & $\begin{array}{l}\text { Heating set } \\
\text { point }\left({ }^{\circ} \mathrm{C}\right)\end{array}$ & \\
\hline $\begin{array}{c}\text { Light } \\
\text { transmittance }\end{array}$ & 0.75 & $\begin{array}{c}\text { Living } \\
\text { spaces }\end{array}$ & 22 \\
\hline $\begin{array}{l}\text { Air tightness } \\
\text { (estimate) }\end{array}$ & & $\begin{array}{c}\text { Other } \\
\text { spaces }\end{array}$ & 19 \\
\hline \multirow[t]{3}{*}{$\mathrm{q}_{50} \mathrm{~m}^{3} /\left(\mathrm{h} \mathrm{m}^{2}\right)$} & 2.60 & $\begin{array}{l}\text { Domestic } \\
\text { hot water } \\
\text { demand } \\
\text { (L/resident/ } \\
\text { day) }\end{array}$ & 65 \\
\hline & & Residents & 108 \\
\hline & & $\begin{array}{l}\text { Heated net } \\
\text { area }\left(\mathrm{m}^{2}\right)\end{array}$ & 3855 \\
\hline $\begin{array}{l}\text { Space heating } \\
\text { demand (MWh) }\end{array}$ & 264 & $\begin{array}{l}\text { Envelope } \\
\text { area }\left(\mathrm{m}^{2}\right)\end{array}$ & 1608 \\
\hline $\begin{array}{l}\text { Domestic hot } \\
\text { water demand } \\
(\mathrm{MWh})\end{array}$ & 256 & $\begin{array}{l}\text { Window } \\
\text { area }\left(\mathrm{m}^{2}\right)\end{array}$ & 315 \\
\hline
\end{tabular}

The annual space heating demand was 264 MWh (68 $\mathrm{kWh} / \mathrm{m}^{2}$ ) and the domestic hot water demand was $256 \mathrm{MWh}\left(66 \mathrm{kWh} / \mathrm{m}^{2}\right)$ for a total of $520 \mathrm{MWh}$ of heating demand. The simulated heating demand was validated using measured values from the real reference building. The simulated results of annual heating demand were within $4 \%$ of the weather-corrected measurements.

\subsubsection{Waste heat potential}

Estimation of waste heat potential can be done by calculating the energy content of the exhaust air and sewage compared to fixed reference temperatures. The building is equipped with mechanical exhaust ventilation with a constant air flow. For most of the year, the exhaust air temperature was determined by the $21^{\circ} \mathrm{C}$ heating set point, while the ventilation rate of the building was fixed at 0.5 air changes per hour $(1400 \mathrm{~L} / \mathrm{s})$. Assuming a post-recovery exhaust temperature of $2{ }^{\circ} \mathrm{C}$, the waste heat power would be $27.5 \mathrm{~kW}$. This corresponds to $240 \mathrm{MWh}$ of annual excess heat from ventilation. The actual value can be increased if higher room temperatures in summertime are accounted for, but it is also influenced by the postrecovery exhaust temperature, which can be higher or lower.

Sewage energy content is determined by the waste water temperature and the total water flow of both hot and cold water consumption. Even cold water is often standing in the pipes and toilets and eventually heated up close to room temperature. Some measurements show average sewage temperatures as high as $24^{\circ} \mathrm{C}$ [8], but a conservative estimate of $20{ }^{\circ} \mathrm{C}$ can be used to account for inefficiencies. To avoid clogging of the sewer due to freezing, the final waste water temperature should not go below $5{ }^{\circ} \mathrm{C}$. The water flow is variable, but in the reference case the average flow was $0.35 \mathrm{~L} / \mathrm{s}$. This results in an average sewage waste heat power of $22 \mathrm{~kW}$ or $193 \mathrm{MWh}$ annual potential.

The simplified waste heat calculation provides a total of $433 \mathrm{MWh}$ of waste heat, which is less than the $520 \mathrm{MWh}$ annual demand. As the recovered waste heat may not be usable during periods of low demand, the waste heat system cannot operate alone and the GSHP system is needed for support.

\subsection{Energy system description}

District heating was utilized in the original building to produce all the required heat. An enhanced system with district heating supported by both ventilation and sewage heat recovery using heat pumps was presented in a previous study [9]. In the current study, the district heating system was replaced by a ground-source and exhaust air heat pump system. Several variants of the same basic system were tested to show the effect of heat recovery and borehole sizing on the cost, energy use and long-term operation potential of the heating system. The system schematic is shown in Figure 1.

The examined energy systems are presented in Table 2. The basic GSHP system was sized according to a rule of thumb that a borehole can produce about $85 \mathrm{kWh} / \mathrm{m}$ of annual heating energy in Finland [10]. The 
Table 2. Studied heating systems.

\begin{tabular}{|c|c|c|c|c|c|c|c|c|}
\hline Scenario & $\begin{array}{c}\text { Primary } \\
\text { heating }\end{array}$ & $\begin{array}{c}\text { Secondary } \\
\text { heating }\end{array}$ & $\begin{array}{c}\text { Ground } \\
\text { connection }\end{array}$ & $\begin{array}{c}\text { Heat pump } \\
\text { capacity } \\
(\mathrm{kW})\end{array}$ & $\begin{array}{c}\text { Number } \\
\text { of } \\
\text { boreholes }\end{array}$ & $\begin{array}{c}\text { Borehole } \\
\text { depth } \\
(\mathrm{m})\end{array}$ & $\begin{array}{c}\text { Borehole } \\
\text { spacing } \\
(\mathrm{m})\end{array}$ & $\begin{array}{c}\text { BTES } \\
\text { area } \\
\left(\mathrm{m}^{2}\right)\end{array}$ \\
\hline 0 & $\begin{array}{c}\text { District } \\
\text { heating }\end{array}$ & No & No & 0 & 0 & - & - & - \\
\hline 1 & GSHP & - & $\begin{array}{c}\text { Extraction } \\
\text { only }\end{array}$ & 160 & 21 & 300 & 15 & 4090 \\
\hline 2 & EAHP & Sewage HP & $\begin{array}{c}\text { Extraction } \\
\text { only }\end{array}$ & $140+15$ & 10 & 100 & 15 & 1950 \\
\hline 3 & EAHP & Sewage HP & $\begin{array}{c}\text { Extraction } \\
\text { \& injection }\end{array}$ & $140+15$ & 10 & 100 & 15 & 1950 \\
\hline 4 & EAHP & Sewage HP & $\begin{array}{c}\text { Extraction } \\
\text { \& injection }\end{array}$ & $140+15$ & 10 & 100 & 5 & 216 \\
\hline
\end{tabular}

number of boreholes in Scenario 1 was obtained by simply dividing the total heating demand with the average borehole output and assuming each borehole was $300 \mathrm{~m}$ deep. When waste heat recovery was included, the supporting borehole field was reduced in size by reducing the number of boreholes and the depth of each borehole. The borehole field (or BTES) was modelled using the TRNSYS Type 557a. The properties of the borehole field are shown in Table 3.

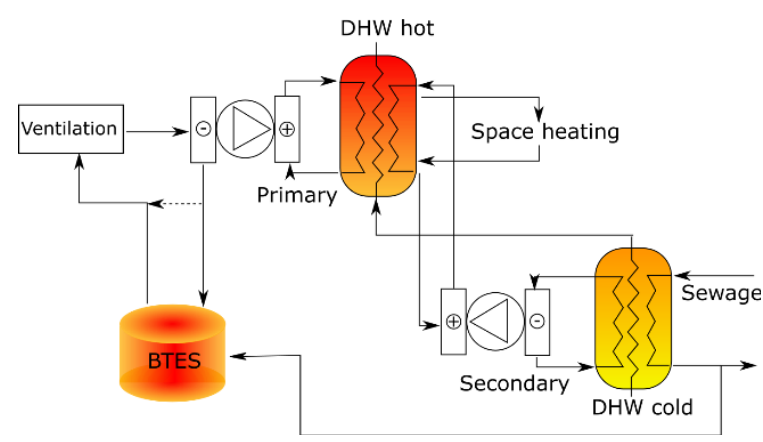

Figure 1. System schematic.

Table 3. Properties of the borehole field.

\begin{tabular}{|c|c|}
\hline Feature & Value \\
\hline Borehole diameter $(\mathrm{cm})$ & 15 \\
\hline $\begin{array}{c}\text { U-tube pipe inner } \\
\text { diameter }(\mathrm{cm})\end{array}$ & 3.2 \\
\hline $\begin{array}{c}\text { Ground heat capacity } \\
\left(\mathrm{kJ} / \mathrm{m}^{3} \mathrm{~K}\right)\end{array}$ & 2200 \\
\hline $\begin{array}{c}\text { Ground thermal } \\
\text { conductivity }(\mathrm{W} /(\mathrm{mK}))\end{array}$ & 3.5 \\
\hline $\begin{array}{c}\text { Fill thermal } \\
\text { conductivity }(\mathrm{W} /(\mathrm{mK}))\end{array}$ & 0.6 \\
\hline $\begin{array}{c}\text { Pipe thermal } \\
\text { conductivity }(\mathrm{W} /(\mathrm{mK}))\end{array}$ & 0.42 \\
\hline $\begin{array}{c}\text { Initial ground } \\
\text { temperature }\left({ }^{\circ} \mathrm{C}\right)\end{array}$ & 5.6 \\
\hline
\end{tabular}

The heat pump performance was based on the NIBE F1345-60 model [11]. On full power, the nominal flow rate was used both on the collector-side and load-side. During part-load operation, the flow rate was adjusted linearly according to the output power. The heat pump performance was based on linear interpolation of the power curves presented in Figure 2. The orange lines show the HP conderser heating rate under different output temperatures $\left(35,50\right.$ and $\left.65^{\circ} \mathrm{C}\right)$ vs. the heat source temperature. The blue lines show the evaporator cooling rate or the heat extracted from the heat source. Various heat pump capacities were modelled by linear scaling compared to the reference $60 \mathrm{~kW} \mathrm{HP}$ model.

The heat pump capacities were chosen on the basis of the peak district heating demand in Scenario 0. In the pure GSHP system (Scenario 1), the total heat pump capacity was $160 \mathrm{~kW}_{\text {th. }}$. In Systems 2-4, the primary heat pump connected to the ventilation and ground loop had a capacity of $140 \mathrm{~kW}_{\text {th }}$, while the secondary heat pump dedicated for sewage heat recovery was sized to $15 \mathrm{~kW}_{\text {th. }}$. The heat pump heat collectors used $30 \%$ ethanol-water mixture as heat transfer fluid (heat capacity $3671 \mathrm{~J} / \mathrm{kg} / \mathrm{K}$, density $937 \mathrm{~kg} / \mathrm{m} 3$ ).

Primary heat storage tank capacity of $3.5 \mathrm{~m}^{3}$ was determined by the heat pump thermal output capacity such that one hour of full output could be stored in the tank. The secondary sewage heat storage tank was $1 \mathrm{~m}^{3}$ in size. The hot water storage tanks were modelled using the TRNSYS Type 534.

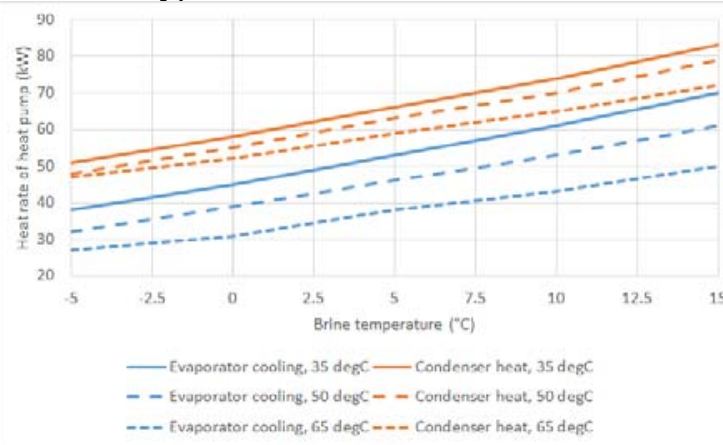

Figure 2. Heat pump (NIBE F1345-60) condenser heating rate and evaporator cooling rate under different heat source temperatures at full capacity. Each curve represents a different output temperature.

\subsection{Control system}

The primary thermal storage tank was divided into six nodes. The top two nodes were mainly reserved for domestic hot water (DHW) priming. In Finland, DHW needs to be provided at $55^{\circ} \mathrm{C}$. To accommodate this, the top node of the primary tank was always kept at $60{ }^{\circ} \mathrm{C}$. 
The four lower nodes were used for DHW preheating and space heating, because space heating typically had lower temperature requirements. The setpoint temperature of the third node was controlled according to the heating curve of the space heating radiators. The DHW flow always went through all six nodes from the bottom to the top. Most of the time, the space heating return flow entered from the bottom node (6) and exited from the third node. However, when the space heating setpoint was raised above $50{ }^{\circ} \mathrm{C}$, the exit node was changed to the top node to take advantage of the whole storage capacity and higher temperatures in the top section. Control switches were implemented in TRNSYS using the differential controller Type 2b, while the heat pumps were controlled with Type 22 .

In the pure GSHP system, $20 \mathrm{~kW}_{\text {th }}$ of heating capacity was dedicated to heating the top section of the tank for DHW. The remaining $140 \mathrm{~kW}_{\text {th }}$ of heating capacity was used for heating the lower section of the tank. This separation was done to prevent constant switching between the two tank sections and to limit the running time of heat pumps in high temperature mode. This improved simulation stability and the COP of the heat pumps.

In the system with ventilation and sewage heat recovery, the top section of the tank was instead heated with the $15 \mathrm{~kW}_{\text {th }}$ sewage heat pump. The lower section of the tank was heated by the exhaust air heat pump, which used both the exhaust air and ground-source heat as a heat source.

In Scenarios 3 and 4, the waste heat flows were directed to the borehole field when the exhaust temperature was higher than the borehole temperature. Similarly, additional heat was extracted from the ground whenever the ground temperature was higher than the return temperature from the primary heat pump. In the ventilation loop, the EAHP source-side return flow was utilized with the BTES. In the sewage loop, the sewage flow after the heat recovery tank was directed to the BTES. In practice, there are some limitations to these connections and these calculations are mainly meant to show the missed potential.

\subsection{Cost data}

The life cycle cost (LCC) was calculated using initial investment costs and energy costs over a 25 year period. The real interest rate was $3 \%$ and the annual energy price escalation was $2 \%$. The investment and energy costs are shown in Table 4.

The EAHP investment included costs related to connecting the ventilation system with the machine room, unrelated to the heat pump itself. In Scenarios 2 to 4 , the EAHP costs were calculated using a capacity of $40 \mathrm{~kW}$ (the capacity is limited by available exhaust air). The remaining heat pump capacity cost was calculated using the Other HP item in Table 4.
Table 4. Cost of system components and electricity (with $24 \%$ VAT).

\begin{tabular}{|l|c|c|}
\hline \multicolumn{1}{|c|}{ System } & Price & Reference \\
\hline Primary tank & $1300 € / \mathrm{m}^{3}$ & {$[12]$} \\
\hline Sewage HR tank & $39000 €$ & {$[13]$} \\
\hline EAHP & $136 € / \mathrm{kW}+94240 €$ & {$[2]$} \\
\hline Other HP & $517 € / \mathrm{kW}+2000 €$ & {$[12]$} \\
\hline Boreholes & $33.5 € / \mathrm{m}$ & {$[14]$} \\
\hline & $4.6 \mathrm{c} / \mathrm{kWh}$ & {$[15]$} \\
\hline Electricity, energy & $\begin{array}{c}2,06 \mathrm{c} / \mathrm{kWh}, \\
\text { winter day }(7-22) \\
1,09 \mathrm{c} / \mathrm{kWh}, \\
\text { other times }\end{array}$ & {$[16]$} \\
$\begin{array}{l}\text { Electricity, } \\
\text { distribution } \\
\text { (Grid fee) }\end{array}$ & $2,79 \mathrm{c} / \mathrm{kWh}$ & {$[16]$} \\
\hline Electricity, tax & & \\
\hline
\end{tabular}

\section{Results}

\subsection{Energy performance}

Figure 3 shows the monthly energy use by heat source in each scenario. The values for the ground are monthly net values, showing the sum of heat extraction (positive) and heat injection (negative). In Scenario 1, all heat was produced by the GSHP with 21 boreholes, which caused a great cooling burden on the ground.

In Scenario 2, heat recovery was enabled and the number of boreholes was reduced to 10 , while the depth was kept at the original $300 \mathrm{~m}$. The waste heat sources provided most of the heating in summer (May to August), which significantly lessened the ground heat extraction during the whole year.

In Scenarios 3 and 4, the ground was charged with excess heat, while the depth of the boreholes was reduced to $100 \mathrm{~m}$. The net heat extraction from the ground was further reduced in the winter months (November to March), as there was always some unrecovered heat that was now stored in the ground. Net heat injection happened from May to September, which provided a significant regenerative energy flow into the ground. Annual net heat extraction from the ground was 361, 116, 2.0 and 1.4 MWh in Scenarios 1 to 4, respectively.

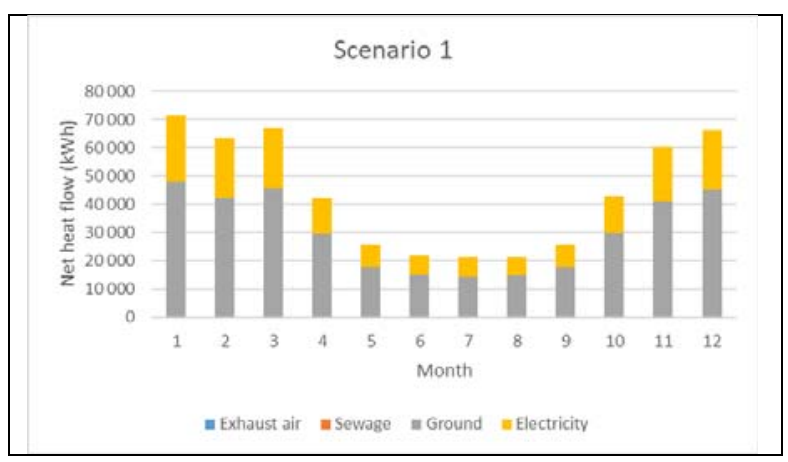




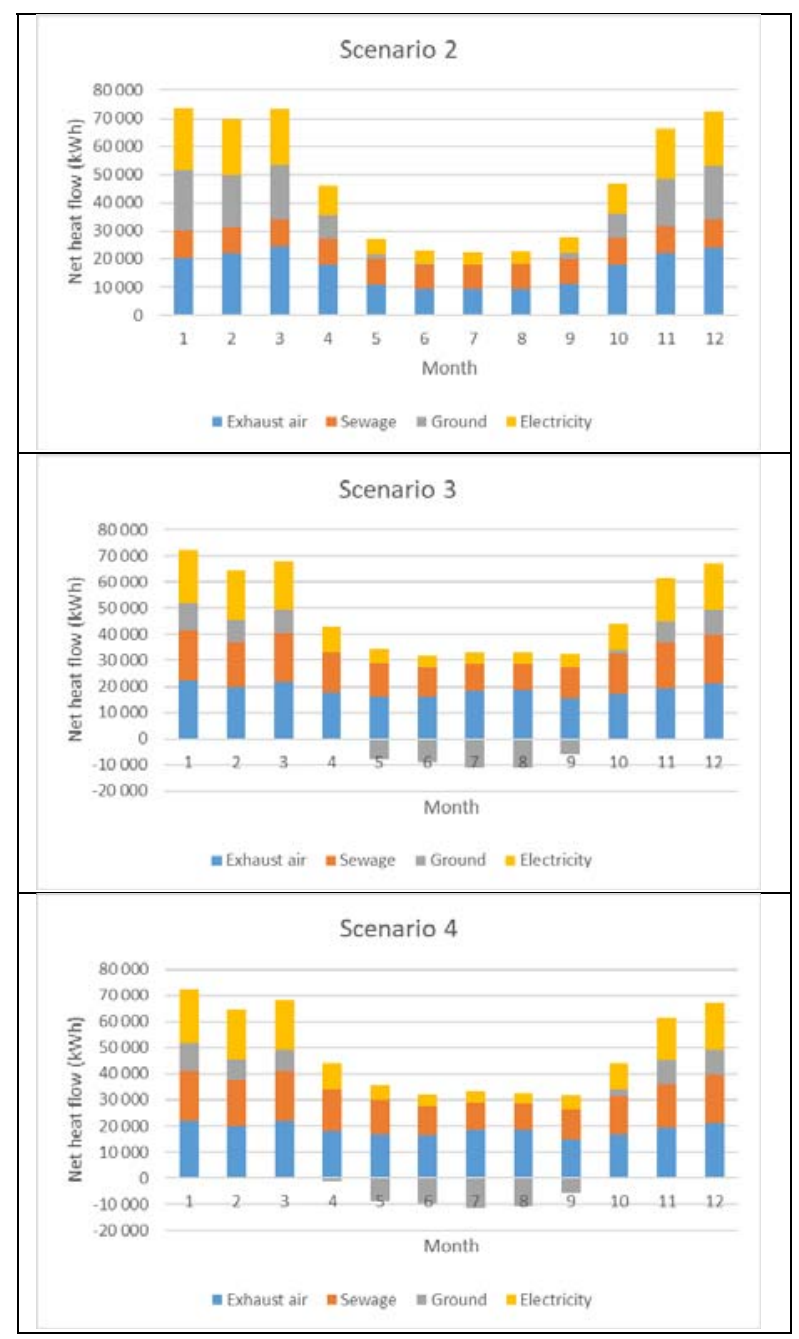

Figure 3. Monthly net heat flow according to heat source in each scenario.

Table 5 shows the recovered waste heat in each scenario alongside the simple estimate from Section 2.1.1. In Scenarios 3 and 4, the amount of recovered heat from exhaust air was increased by $12 \%$ compared to Scenario 2, while sewage heat recovery was increased by $61 \%$. Utilizing the thermal storage capacity of the ground brought the realized potential of both heat sources within $92 \%$ of the simple estimate.

Table 5. Potential and realized waste heat recovery.

\begin{tabular}{|c|c|c|}
\hline Scenario & $\begin{array}{c}\text { Exhaust air } \\
(\mathrm{MWh})\end{array}$ & $\begin{array}{c}\text { Sewage } \\
(\mathrm{MWh})\end{array}$ \\
\hline Simple estimate & 240 & 193 \\
\hline 1 & 0 & 0 \\
\hline 2 & 199 & 111 \\
\hline 3 & 223 & 178 \\
\hline 4 & 223 & 178 \\
\hline
\end{tabular}

\subsection{Temperature performance}

Figure 4 shows the development of the borehole field temperatures in each of the scenarios. In Scenario 1, where all heating energy was produced by the GSHP, the natural regeneration could not compensate for the annual heat extraction. Each year the ground temperature went down further, losing $1.6 \mathrm{~K}$ over five years. If the changes between the $3^{\text {rd }}$ and $5^{\text {th }}$ year are extrapolated, the ground would end up at $0{ }^{\circ} \mathrm{C}$ after 20 years of operation. This would result in gradual reduction in the heat pump performance. On the other hand, this performance reduction would also slow the rate of temperature degradation.

In Scenario 2, which included waste heat recovery but no charging of the ground, the ground temperature was reduced to $4.7^{\circ} \mathrm{C}$. The drop in the first years was the greatest, and extrapolating based on the $3^{\text {rd }}$ and $5^{\text {th }}$ year, the final temperature in 20 years would be $2.7^{\circ} \mathrm{C}$.

In Scenario 3, where unutilized waste heat was injected to the ground, after five years of operation, the ground temperature remained the same as at the start $\left(5.6^{\circ} \mathrm{C}\right)$, showing how regeneration by waste heat can enable sustainable use of the ground heat.

Finally in Scenario 4, the waste heat was injected to the ground, but the storage volume and thus the total heat capacity were much smaller, due to shorter distances between the boreholes. This made the seasonal temperature fluctuation much larger than in the other cases. After five years, the temperature had gone down to $5.2{ }^{\circ} \mathrm{C}$. However, at this point the seasonal average ground temperature was stabilized and would remain at the same level until the 20 year mark.

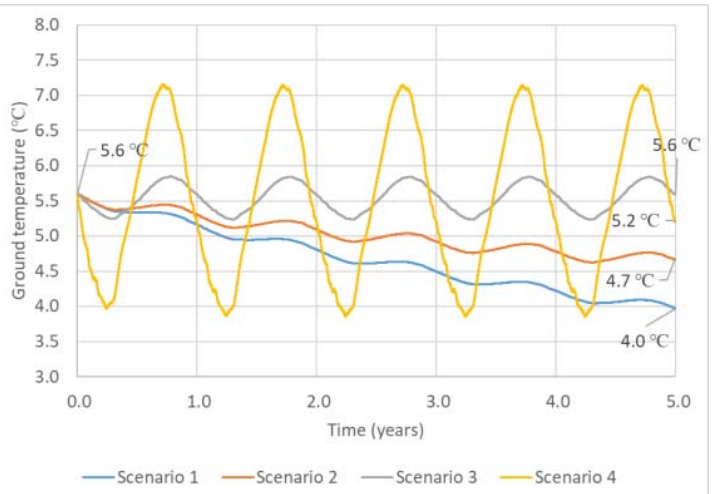

Figure 4. Borehole field temperature development.

\subsection{Cost analysis}

The initial, annual and life cycle costs of each examined scenario are shown in Table 6 . The electricity costs for the whole period were calculated using the energy consumption profile of the fifth year. The main difference in the cases was that the borehole investment was reduced by $52 \%$ in Scenario 2 and $84 \%$ in Scenarios 3 and 4 compared to Scenario 1. Additional investments were made to heat recovery systems, but the life cycle cost of Scenarios 2 to 4 was clearly lower than in Scenario 1. The lowest cost was obtained using the seasonal storage of waste heat. The LCC in the hybrid system Scenarios 3 and 4 was 20\% lower than in the pure GSHP Scenario 1. 
Table 6. Scenario costs.

\begin{tabular}{|c|c|c|c|}
\hline Scenario & $\begin{array}{c}\text { Investment } \\
(€)\end{array}$ & $\begin{array}{c}\text { Electricity } \\
(€ / \mathrm{a})\end{array}$ & $\begin{array}{c}\text { LCC } \\
(€ / 25 \mathrm{a})\end{array}$ \\
\hline 1 & 300272 & 14849 & 628090 \\
\hline 2 & 307826 & 12780 & 589969 \\
\hline 3 & 240826 & 12031 & 506430 \\
\hline 4 & 240826 & 12035 & 506514 \\
\hline
\end{tabular}

\section{Discussion}

This study shows that more residential waste heat could be utilized with seasonal thermal energy storage. The waste heat storage allows tighter spacing of boreholes, enabling GSHP systems to be used even when there is not much space available. However, the practical implementation of the connection between the borehole field and waste heat sources needs further consideration, as the simulated setup may not be feasible as it is. Instead of redirecting the sewage flow after the HR tank, there could be a system that constantly drains the HR tank, keeping its temperature within some lower limits. The electricity consumption of pumping not related to heat pumps was ignored. This makes the results of seasonal heat storage somewhat optimistic.

Better prioritization of the sewage heat pump could improve system performance. This would increase the complexity of the control system. Additional study is needed to develop optimal controls.

Further study on the topic of waste heat storage could be done on modern buildings with existing heat exchanger -based ventilation heat recovery system. The additional investment cost would be lower when the ventilation system is up to code from the start. Lower heat distribution temperature would also improve total efficiency of a heat pump system.

When estimating the temperature reduction in the ground, it was assumed that the energy drain on the ground would remain stable after five years. However, as the ground temperature is reduced, the heat pump will obtain a decreasing share of its energy from the ground, reducing the temperature drop. In practice, the groundfreezing might take longer than estimated here.

The heat pump model has not been validated experimentally. However, depending on the heat source and output temperature, the seasonal performance factors of the simulated heat pumps were between 2.5 and 3.5, which are typical values for such systems. A pilot case is needed to implement the system and the related controls in practice.

\section{Conclusions}

This study shows that the utilization of residential waste heat sources in apartment buildings can reduce heating costs compared to pure ground-source heat pump system. Hybrid ground-source / waste heat systems also significantly reduced the ground footprint of the heating system, making it more feasible to install a GSHP-based heating system in urban environments constrained by the lack of space. Storing the excess heat from the building into the ground prevents the gradual cooling of the borehole field, making the GSHP system work sustainably for an indefinite period.

In the pure GSHP system sized according to common guidelines, the ground could freeze over the long term. With direct waste heat recovery, the number of required boreholes was decreased and the horizontal borehole field size was reduced by $52 \%$ compared to the pure GSHP case. When waste heat was stored in the borehole field, the total borehole length was significantly reduced, but most importantly the required land area was cut by $95 \%$, while stabilizing the ground temperature with regeneration by waste heat. The life cycle cost of hybrid cases with seasonal waste heat storage was $20 \%$ lower than in the pure GSHP case.

Further studies are needed to design a more practical system and to optimize the component capacities and control systems. A pilot system with monitoring needs to be built to confirm the effects of the regeneration.

This study is part of the "New business and collaboration models for efficient waste heat recovery and heat storage in the built environment" (HUKATON)-project and the FINEST Twins project. The HUKATON project is funded by European Regional Development Fund (ERDF), City of Helsinki and Helen Ltd. and the FINEST Twins project is co-funded by the European Union (Horizon 2020 programme, Grant No. 856602 ) and the Estonian government. The study was also funded by the Academy of Finland (grant number 309064). The authors would like to thank Green Net Finland, Heka Ltd. and Ecopal Ltd. for fruitful co-operation.

\section{References}

[1] S. Paiho, S. Pulakka, and A. Knuuti, "Life-cycle cost analyses of heat pump concepts for Finnish new nearly zero energy residential buildings," Energy and Buildings, vol. 150, pp. 396-402, Sep. 2017.

[2] T. Niemelä, R. Kosonen, and J. Jokisalo, “Energy performance and environmental impact analysis of cost-optimal renovation solutions of large panel apartment buildings in Finland," Sustainable Cities and Society, vol. 32, pp. 9-30, Jul. 2017.

[3] J. Kensby, A. Trüschel, and J. O. Dalenbäck, "Heat source shifting in buildings supplied by district heating and exhaust air heat pump," Energy Procedia, vol. 116, pp. 470-480, Jun. 2017.

[4] Z. Qunli, N. Qian, L. Fang, and Y. Chaohui, "Technology and Economic Analysis of Sewage Source Heat Pump Combined Type District Heating Method," Energy Procedia, vol. 142, pp. 1312-1318, Dec. 2017.

[5] S. Miglani, K. Orehounig, and J. Carmeliet, "Integrating a thermal model of ground source heat pumps and solar regeneration within building energy system optimization," Applied Energy, vol. 218, pp. 78-94, May 2018.

[6] K. Allaerts, M. Coomans, and R. Salenbien, "Hybrid ground-source heat pump system with 
active air source regeneration," Energy Conversion and Management, vol. 90, pp. 230237, Jan. 2015.

[7] M. Szulgowska-Zgrzywa and N. FidorówKaprawy, "Performance analysis of a brine-towater heat pump and of its boreholes' temperature change during three years of operation," Applied Thermal Engineering, vol. 127, pp. 233-244, Dec. 2017.

[8] E.-P. Koikkalainen, "Management of energy flows and power peaks in high-rise buildings," M.Sc. thesis, Aalto University, Espoo, Finland, 2016.

[9] J. Hirvonen, J. Jokisalo, and R. Kosonen, "Numerical analysis of heat recovery options in old Finnish apartment buildings," presented at the BuildSim-Nordic 2020, 2020, pp. 252-259.

[10] Gebwell Oy, "3 kohtaa joilla varmistat maalämpöprojektisi onnistumisen ( 3 points to guarantee the success of your ground heat project) [In Finnish]." Gebwell Oy, Jul-2019.

[11] NIBE AB, "NIBE F1345 heat pump," NIBE F1345 heat pump, 2020. [Online]. Available: https://www.nibe.eu/en-eu/products/heatpumps/ground-source-heat-pumps/NIBE-F1345-32. [Accessed: 11-Jan-2021].

[12] Taloon.com, "Taloon.com web store," 2019. [Online]. Available: https://www.taloon.com. [Accessed: 03-Dec-2019].

[13] Wasenco Oy, "Telephone conversation with Wasenco CEO,” Wasenco, 14-Jan-2021. [Online]. Available: http://wasenco.com/en/. [Accessed: 14Jan-2021].

[14] J. Hirvonen and K. Sirén, “A novel fully electrified solar heating system with a high renewable fraction - Optimal designs for a high latitude community," Renewable Energy, vol. 127, pp. 298-309, 2018.

[15] Nord Pool, "Historical electricity market data," 2018. [Online]. Available: https://www.nordpoolgroup.com/historicalmarket-data/. [Accessed: 14-Jan-2019].

[16] Helen Oy, "Sähkön siirtohinnat Helsingissä (Electricity distribution prices in Helsinki)," 2020. [Online]. Available: https://www.helensahkoverkko.fi/palvelut/hinnast ot. [Accessed: 23-Jun-2020]. 